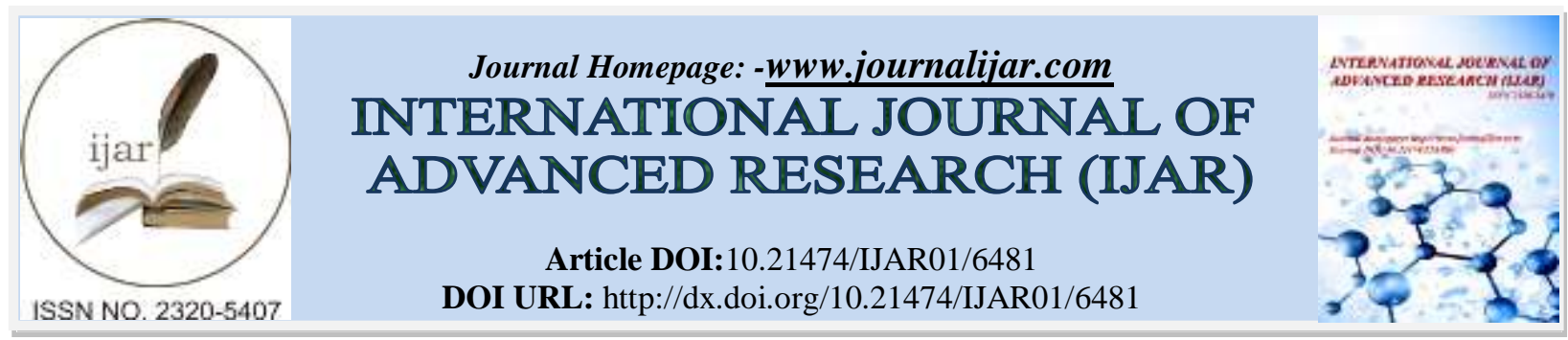

RESEARCH ARTICLE

\title{
INCULCATION OF MORAL VALUES AMONG SCHOOL CHILDREN IN TELANGANA: THEN AND NOW.
}

\begin{abstract}
Mr. Sreeramulu Gosikonda ${ }^{1}$ and Dr. Nagaraju Gundemeda ${ }^{2}$.
1. Lecturer in Sociology, Department of Agricultural Science \& Rural Development, Loyola Academy Degree \& P.G. College, Secunderabad, Hyderabad, Telangana State, India.

2. Professor, Department of Sociology, School of Social Sciences, University of Hyderabad, Prof. C.R. Rao Road, Hyderabad, Telangana State, India.
\end{abstract}

\section{Manuscript Info}

\section{Manuscript History}

Received: 09 December 2017

Final Accepted: 11 January 2018

Published: February 2018

Keywords:-

moral values, status of teacher, punishment, discipline, student, Telangana.

\section{Abstract}

School is an important agent of socialization process to the human beings. That is why school education plays an important role in one's life. It is the foundation for development of any society. The teacher is the renowned person in the process of education. According to Hindu mythology, teacher is called as Guru, who is treated as Lords Brahma, Vishnu and Maheshwara. The Guru used to train his disciples at his 'Ashrams' which were also called as 'Gurukula' during Vedic period in India. The teacher has given utmost priority and received great respect from the society during those days. A Sanskrit shloka, 'Mathrudevobhava, Pithrudevobhava, Acharyadevobhava, Athididevobhava' indicates that mother, father, teacher and guest are treated like god. Only the Brahmins were eligible to work as teachers during ancient period. After India got freedom from the British, educational facilities were expanded in a massive manner throughout the country. So that most of the educated youth belong to various castes have chosen the teaching profession by interest. Hence there is a shift in the teaching profession in India i.e. 'from Brahmin to Bahujan'. But in the case of Telangana region, which formed as $29^{\text {th }}$ State of Indian Union on $2^{\text {nd }}$ June, 2014, the teaching community has been changing for the last several decades. During the Nizam period, where Telangana was part of Hyderabad state, majority of the teachers were Muslims. After it was merged with Indian Union in 1948, the government has recruited Hindu teachers as part of promoting Telugu as medium of instruction at school level. Currently, most of the parents are sending their children to private schools. According to Durkheim society is the source of all moral authority. Man is a rule-making animal, and the customs, laws, maxims and opinions of the group are the basis of morals. He sees teacher as the representative of the authority of society, who must take the role of a leader, and develop in his students a taste for the morality of group life. The school itself is a small society acting as a link between the family and outside world. He proposed a model of the teacher today is that of a fellow worker with his pupils, a planner of learning situations and one who works with far less assurance of the desired result than the teacher of the past. 
At this juncture the present paper aims to find out various methods of inculcation of moral values among children in Telangana during different periods. The paper traces out factors responsible for decreasing status of teachers in Telangana. The paper also exhibits and highlights personal experiences of retired teachers, which are related to above mentioned themes. The study is based on empirical research conducted in a town of Telangana State. In depth interviews with retired teachers have conducted in the year of 2015. The study finds that due to globalization and commercialization of education, the inculcation of moral values is not given much priority in the schools when compared to the past.

Copy Right, IJAR, 2018,. All rights reserved.

\section{Introduction:-}

The Madras Presidency was under the British control until India got independence in 1947. The Telugu speaking regions namely Coastal Andhra and Rayalaseema of the Madras Presidency were detached to form a separate State of Andhra on $1^{\text {st }}$ October 1953. These regions witnessed British system of education where the medium of instruction was Telugu as well as English.By the time, Telangana was part of the erstwhile State of Hyderabad, whichwas ruled by the Nizam government. The government encouraged Urdu medium schools for promoting Urdu language and intentionally neglected the regional languages. The main aim of educational system was spreading Islamic culture. Some of the Christian missionaries started English medium schools in Hyderabad city and also in few major towns of the State. Because of this reason most of the non-Urdu speaking population i.e. Telugu, Maratha and Kannada people were away from attending schools due to language problem. In fact the non-Urdu speaking population was more than the Urdu speaking population. Telangana was dominated by Telugu people and also they demanded the government that school education should be provided in Telugu itself. It was the state that influence the life of people by controlling education system directly.Hyderabad State was merged with Indian Union on $17^{\text {th }}$ September 1948 by military operation called 'operation Polo' and continued as a separate state for six years. The caretaker government made a provision to impart education in Telugu, Marathi and Kannada in the government schools.On $1^{\text {st }}$ November 1956, Telangana was merged with the Andhra State to form the state of Andhra Pradesh with Hyderabad city as its capital. There was a movement for formation of separate Telangana state in the year of 1969 which did not achieve success.Again the movement was reached to peak level in the period of 2010 - 2014 . Due to socio-economic-political reasons, Telangana formed as a new state of Indian Union in the year of 2014. Hence, the education system of Telangana hasinfluenced by the Nizams unlike Andhra, which was influenced by the British India.

During Nizam period, High schools (Fokania), Middle schools (Vasthania) and Primary schools(Thahathania) used to be continuing at District Headquarters, Taluque Headquarters and some selected big villages respectively. In all levels of school education Urdu was the medium of instruction. SadarMudiris (Head Master), Mudiris (Teacher of various subjects), Drill Master, Drawing Master, Technical Teacher (Nazarik/Dasyafth) and Gardening Teacher were the various types of teachers worked in schools during Nizam period. In Telangana, HSC (Higher Secondary Certificate) of 11 years study was in vogue until SSC (Secondary School Certificate) of 10 years course was introduced in 1969 .

\section{Types of Schools during Nizam Period:-}

Under the management of Nizam government two types of schools were there. Junior Basic Schools used to have the classes from I to V. Senior Basic Schools used to have the classes from I to VII. Sageer (Infant) class was for one year which gave the foundation on alphabets to the newly joined children. There was no school run by the private management with government permission. But some of the persons belong to Brahmin or Vysya caste used to run Khangi (private) schools in the villages for their livelihood. The main aim of the teacher was not only imparting basics (LSRW) in Telugu and Urdu but also inculcation of moral values among students. Teacher used to teach in Telugu, which was the mother tongue of majority of the population. Teacher used to teach moral stories, moral poems, Telugu months and years, tables, basic mathematics and measurements in daily life. Khangi schools impart education to the students up to $4^{\text {th }}$ class only. Later they used to prepare the students for getting admissions in government schools, where the medium of instruction was Urdu. Hence the teacher of Khangi School used to teach in Telugu as well as Urdu. 


\section{Objectives:-}

The present paper "Inculcation of Moral Values among School Children in Telangana: Then and Now" is going to be carried out with the following objectives. They are

1. To analyze the various methods of inculcation of moral values among school children in Telangana from Nizam period to Neo-liberal period.

2. To find out the factors responsible for decreasing status of teachers in Telangana.

\section{Methodology:-}

The study is based on empirical research conducted in Huzurabad town of Karimnagar District, which has been witnessing political, administrative and educational changes for the last one century. Both primary and secondary sources were used for gathering data. The researcher considered the retired teachers as the primary source to find out the changing trends in inculcation of moral education among school children from 1940 to 2015. The retired teachers have experienced the system of school education for three generations. They observed the greatness of their teachers and practiced the same in schools as teachers. As the parents, they have personal experience on schooling of their children. They have witnessed the changes that took place in school education from their student life to their grandchildren's student life. In a simple manner, the retired teachers as students, as parents cum teachers and as grandparents can able to differentiate, analyze and asses the system of school education during various periods. Snow ball technique was used for identifying the respondents. The researcher selected around 35 retired teachers and conducted in depth interviews with them by using structured interview schedule which consists of quantitative as well as qualitative types of data.

\section{Theoretical Framework:-}

The present paper adopted the Durkheim's theory on moral education, where the moral values are going to be changed according to the changes taken place in any society. Since man's nature is not fixed and there is no limit to his future possibilities. When the society undergoes rapid changes, we have to re-create our moral standards to fit to the new conditions to avoid anomie. According to Durkheim (1925) each class develops a special group spirit of its own and tends to develop its own local norms and standards. He thinks it is going too far to let the class be a sort of tribunal to judge the conduct of its members', yet he accepts some degree of self-government by suggesting that the class should be consulted on rules and penalties, and decides that the master should hesitate to give a type of punishment against the general opinion. The child can also come to see duty as good and desirable, whenever he is given his own share of responsibility. The individual becomes truly himself and realizes his full nature through his life in society. When the rules and habits of his group internalized in the individual they become a part of his own ends and gain respect. We are part of society and society is part of us. Values arise and change in society according to the needs of its group life.

Blackledge and Hunt (1985) says that Durkheim gives a significant role to education as its main function is to maintain stability in society and socialize human being. The school must build on susceptibility to develop spirit of discipline, where rules are very important. When a child enters the school, he/she is faced with rules that bind him/her and others equally. These rules are more general than one has experienced at home. Punishment is important, which shows the child that the rules are binding on all and worthy of respect. Physical punishment would be counterproductive since it offends against the basic principle of modern morality i.e. respect for the dignity of man. The school must give the child an image of the group to which he/she belongs. Each class has a personality of its own so that the teacher as a director of the class must develop its unity and solidarity. Collective punishments and rewards can be used for this purpose. The children should know the reason for acting morally. Therefore, they must have an understanding of their own society and its needs.

\section{Findings and Discussion:-}

Some of the retired teachers have studied during Nizam period in Urdu medium schools. Most of the retired teachers have studied in Khangi schools as well as government schools. Most of a time, upper caste students used to attend the school where the proportion of marginalized sections of the society is negligible. The forthcoming paragraphs of the paper are going to illustrates on the views of retired teachers with their personal experiences on various elements/components involved in inculcation of moral values among children. 


\section{Dedication of Teachers:-}

The retired teachers remember that their teachers are very much interest in teaching more than one subject. They want to justify the students andsome of them teach three subjects also. If they are perfect in games and sports, they try to give training to the children. If there is any vacancy in the school, the teachers try to adjust themselves and share the periods of vacant subject according to their interest. Ultimately, they workfor the students' welfare. Apart from their salary, they don't expect anything. They feel that since they are taking salaries, they have to justify the students.

\section{Teachers' Stay:-}

Most of the teachers who worked at Huzurabad belong to various places of Hyderabad state. Most of the teachers belong to Muslim religion, except who teach Telugu language. Poor transport facilities are there during those days. Only one private bus service hadbeen operating between Warangal and Karimnagar by Mr. Nizamuddin, who belonged to Korutla of Karimnagar District. The bus used to go to Warangal from Karimnagar in the morning and it come back to Karimnagar in the evening daily. Due to lack of transport facilities, the teachers used to stay at working place with their family. They bring their children to the same school for education. The farmers used to give their crops like food grains, pulses and vegetables to the teachers freely during those days.

Mr. A. Rajanna (82, M) says, "I took first appointment as government teacher at Marripalligudemvillage in 1953 and stayed there itself in a rented house."

Mr. M. Ramaswamy (73, M), says "I stayed at Kondapakavillage as a teacher from 1966-70. Most of the farmers used to bring their crop production in baskets for me."

\section{Subjects and Syllabus:-}

The subjects used to teach to the students during Nizam period were Riaz/Hissab, TariqueGeographia, Urdu (Osmania) and Ikhlaqiat (Moral education). There used to be seven subjects being taught from VIII-X classes. Three languages were taught - Telugu, English and Hindi, Elementary Mathematics, History Geography and General Science. Students used to elect either Optional Mathematics or History of England. Composite Mathematics, Sanskrit and British History were the optional subjects at H.S.C. Students had to elect any one of the subject. Domestic science was compulsory subject for women.

Gardening was the main extra-curricular work for students. They used to grow palak, chukka, bhendi, onion, coriander and fenugreek. Apart from gardening, once in a week, the school conducted a craft class where students learn book binding and carpentry. Later on drawing, dasthakari (craft/carpentry), gardening, spinning cotton with charkha, weaving and drill were taught to children as part of basic education.

\section{Games and Sports:-}

Most of the retired teachers participated actively in games and sportsfor physical fitness and mind relaxation during their school days. After the regular classes, the school ground is used to occupy by the students in the evenings on all working days. Games are compulsory for all which improves the team spirit, co-operation and healthy competition among the students. Mass drill was conducted weekly once for the classes of VI-X. For each day they have to play different games and sports. The games played by the students were kabaddi, kho-kho, carroms, short put, high jump, long jump, and tennicoit, through ball, football, volleyball, basketball, badminton, hockey and other rural games.

\section{Role of Teacher in Clarifying Doubts:-}

Most of the retired teachers say that they clarify doubts by consulting class leader. If he/she doesn't know, then only they meet the subject teacher collectively. Most of them say that if they want to ask for any clarification/doubt/question, it would be providing a chance for teacher to pose another related question to them. In order to avoid this problem, they sit silently in the class room. However, the teacher always welcomes the doubts and ready to clarify them. But the students don't have enough courage to talk to the teachers for discussing any matter. The students believe in the teachers that they never teach lies to them. The teachers never lead the students in a wrong direction. The teacher wants to share the information whatever they know to improve knowledge of students. They didn't want to get any complaints either from higher authorities or from parents. They didn't want to point others for their mistakes and failures. In the same way, they didn't like to be pointed out by others. The teacher 
was dedicated, committed, duty minded, calm going, and impartial, secular, non-political, highly respectable and noble person.

Mr. Hanumaiah, $(65, \mathrm{M})$, says, "If we ask one question, then we have a fear that he may ask another question. To avoid this we try to sit silently and respond by moving our heads. When the teacher asks for clarifying any doubts, we used to say that we understood the lesson. The students believe that whatever is said/teach by the teacher is the 'vedam' (final). We don't have enough books and resources for information. We depend on teacher only and consider him as son of Saraswathi, who is the Goddess of Education. Hence, we treat teacher is the treasurer of knowledge."

\section{Rules and Discipline:-}

The teacher was perfect and the teacher is always seen having a cause in his hand to discipline the students. The teacher was dictator. The teachers follow the rules and regulations strictly. The teachers think that if they follow rules and regulations perfectly, their students will also follow/imitate them. They don't like to receive any complaints regarding their punctuality and discipline. So that the students also don't want to attend the school by late. If they were late, they have to take permission from the 'Chaprasi' (attender) to enter into the classroom. The students fear of even attender also during those days. The attender used to go every home and bring the students to school. Whenever attender came near to home, the students try to escape from their home and hide themselves.

Mr. G. Rajanna (73, M) says "I went to a Khangi school, which is near to my home at Huzurabad. The teacher never demands for fee. Even though the teacher has anger, we have a feeling that he explains everything and takes care all with affection."

Mr. Agaiah (70, M) says, "We don't know what is copying in examinations. Detention system is there in those days. So, every student is serious in preparing and writing examinations. If we turn our heads, the teachers used to send us out without writing examination. Besides, we have another fear that if we fail, we have to stop our studies because of poverty."

\section{Character Building and Discipline among Students:-}

Character is more important in one's life. Without character and discipline, education is waste. Even the textbooks also focus on these themes. Most of the lessons in Telugu language were being selected from Bhagavad-Gita, Mahabharata, Ramayana and other great epics and books of Ancient India, which reflect the culture of India. The teachers are ideal to the students in those days. Most of the retired teachers say that they inspired by some of their teachers and achieved their goals. The students know the meaning and importance of character and discipline from their teachers only. They learn character and discipline by imitating their teachers.

Most of the teachers have good habits. By selecting teaching profession itself, they want to be ideal and role model to others so that they have good habits. They know very well about the status of teacher and respect for teacher in the society. They learn moral values from their teachers and they want to transform the same to their children/students. They also know that practicing moral values in daily life is the best policy for inculcation of the moral values among the students. In this way, the students imitate the teachers, if they follow moral values perfectly. Otherwise the students question the teachers, if they find any difference between preaching and practicing of moral values. Even though some of the teachers have bad habits, they never expose those to the students. If the teachers have any bad habits, they treat those as personal by maintaining secrete and they try to expose good habits only for the sake of students. If the bad habits of the teachers are known to the students, they are easily attracted to those than the good habits. In this way the teachers build up good discipline and character among the students.

Mrs. Mahaboobunnisa Begum $(68, \mathrm{~F})$ says, "If character is lost, everything is lost."

\section{Inculcation of Moral Values among Students:-}

The teacher should teach the students about 'Chaduvu - Samskaram', which means education and culture. The students observe the honesty of parents and teachers. If the parents and teachers follow moral values, the children will imitate them. This is one of the best ways for inculcation of moral values among the children. The teachers stress on moral values not only theoretically but also practically. They live with morals. Honesty is one of the moral values, which has practiced by most of the teachers in their service. According to Hindu tradition, mother, father, teacher and guest are treated as god. 
Students learn many things from lessons. Teachers also teach the lessons to understand and follow the essence of lesson in students' life. Even the popular Telugu poems selected from several Shatakamulu, which is a volume of hundred poems like Vemana, Sumathi, Bharthruhari, Daasharathi, Bhaskara, Narasimha and Sri Kalahastiswarawritten by famous poetsVema Reddy, Baddena, LaxmanaKavi, KancharlaGopanna, Venkayya, Seshappa and Doorjati respectively. The poems focus on the real condition of society and emphasize on the importance of moral values in those days. The teachers used to sing the poems according to grammar in an interesting way and explain the theme in a story form to make the students understandeasily. They also give live examples to the students for the need and necessity of moral values in society. The teachers not only preach moral values but also practice those values, which makes them as role models for their students. The students fix their goals in the school itself and take their favorite teacher as inspiration to achieve their goal in future. Honesty, justice, sincerity, duty minded, responsibility, good character, discipline, co-operation, respect to elders and belief in the Indian family system are some of the moral values of retired teachers, which they have learnt from their teachers. Language teachers have more responsibility in inculcating moral values among students. They can explain the consequences if one person has not followed moral values as part of their lesson.

Moral values can be inculcated among children by reading books also. But now-a-days libraries are not available in many of the schools. Even students have too work load to read books other than academics. Even the parents and school managements are least bothering about inculcation of moral values among children. Most of the parents want to see their children as toppers either in Sciences or in English language to earn a good position in future life. Even the school managements want to get more marks for attracting as many students as possible. In some of the schools, the classes allotted for Telugu per week is very less when compared to other school subjects like Mathematics, Physical Sciences, Biology and English.

Moral education means preparing good citizens for the development of society.Moral education is necessary for children from nursery class onwards. It should be included in the curriculum itself. The impact of media is more on the children and they will be attracted to the negative things easily. Most of the serials telecast in various channels focus on family conflicts, kidnaps, rape cases and taking revenges on others etc. which affects the behavior of children in future. Media is not bothering about inculcation of moral values among children rather they compete for increase for ratings. Grandparents are good agents of inculcating moral values among the children by telling various stories. But due to nuclear families the students are missing the association of grandparents during their school life. Currently, both nuclear families and old age homes are increasing in India. Since wife and husband go for job in towns and cities, day care schools are coming. If the situation continues for several years, the students, who are the citizens of tomorrow, will measure everything in rupees and dollars. Students will not have any sentiments and they will not care for relations. Because of these reasons, there is a need to inculcate moral values among the children. Now-a-days priority has increased for job oriented education rather than moral education.

Mr. Adhi Narayana (76, M) says, "We have lived in moral era where human values and moral values are given importance. Now it is the era of science, where the inventions play important role and values are given less priority." Mr. V. Jaganmohana Chary (70, M), says, "If we see a teacher, all values will be appeared in him and the student takes him as a model. If they have any bad habits, they maintain secrete to avoid bad name to the teacher community and also to stop negative impact on students. The motto of the teachers in those days is to serve the student is to serve the nation."

Mr. Veera Swamy (65, M) says "We played dramas in schools. During my schools days, Subhashithalu(moral poems) motivate/inspire us to practice values in ourlife. But now, those poems are for getting marks only. Neither the teachers nor the students try to practice in their life."

Mrs. MunthajJaha $(62$, F) says "I inspired by my school teachers. I think that I have to behave like my favorite teacher, if I become a teacher. I wanted to inspire my students like how my teachers inspired me. I wanted to become a role model for my students."

Mr. Rangaiah (74, M) says "The teacher follows a systematic, disciplined and simple lifestyle so that the students also imitate the teachers in those days. If any teacher had bad habits, he took care to not expose to the students. He maintained secrete. Now, whatever bad habit followed by any teacher, it is known to the students. In this way, teacher has lost his power to inculcate moral values and good habits." 


\section{Modes of Punishment to the Students:-}

The retired teachers say that because of the fear only, they got education to become teachers. In government schools kennings was common as punishment given by the teachers. Severe punishment like 'Kodandam' was there in the Khangi schools. Hanging to the tree in reverse and keeping thorns on the ground is called as Kodandam, which is also accepted by the parents for bringing change in the behavior of students. Generally, this punishment would be given to the arrogant students who are not listening to parents and teachers, telling lies, irregularity in attendance, making noise in classroom, arguing and questioning with parents and teachers, involve in the anti-social activities and also for not completing the task related to academics assigned by the teacher for a long time. Pinching the thighs, pinching ears and slapping are some of the punishments given by the teachers directly by using their hands. Asking the students to stand outside or within the classroom or on bench, gunjeelu(holding ears with hands crossing each other and alternate between standing and squatting), baskilu (requesting for forgiveness for any mistake by holding ears with hands crossing each other), wall chair also known as Jetliner position/captain's chair (putting back against a wall where feet are usually kept close together and then slide down the wall until thighs are parallel to the ground) and murga(taking a position resembling that of a rooster, by squatting and then looping the arms behind the knees and firmly holding the ears) are other forms of punishments. Among these murga is the severe punishment. Sometimes, the teachers use to give punishment by beating on either sides of the palms with cane (a splendor and sharp stick). Finally the girls used to slap boys for their less performance in academics as the punishment assigned by the teacher. Anyhow, the punishment is severe in the primary schools whereas punishment is mild in the high schools. The teachers think that students can able to know the school culture when they enter into high school. Simply the students have to listen to the teachers, if they want to improve knowledge.

Now-a-days, teachers should afraid of students. No punishment should be given to the students. The school managements give clear instructions to the teachers regarding ban on corporal punishment in schools. The policies and parents are against to the corporal punishment. Even the media wants to highlight the issues related to punishment in schools. So that the teacher has to teach the lesson and he/she has no right to punish them. The teachers also think that they don't want to take any risk and they would like to work according to the salary they are drawing. Simply the teachers are following 'bell and bill policy'. At present, the teachers should have patience and improve the knowledge levels among the students. The main duty of the teacher is to complete the syllabus in a prescribed time. Teacher has to help the students in scoring good marks in his/her subject. No teacher is bothering on inculcating moral values among the students. Teachers are not giving any additional information to the students except the information given in the text books. There is a negative response from the students and parents, if a teacher punishes any student. Parents are giving lenience to their children due to having one child or two children only and they create a feeling that the teacher is also like a common man, whose salary is being paid by them indirectly in the form of paying fee to the school. After introducing CCE (Continuous and Comprehensive Evaluation) model in Telangana, students are copying the content and pastingit in their project reports, which delimits them just gathering information only without proper understanding, application and analysis of various concepts. In this way the role of teacher is minimized, mechanical and limited. Hence most of the students are not giving respect to the teachers.

\section{Response of Parents on Punishment to the Students:-}

The retired teachers reminded that their parents only asked the teachers to punish their children for changing behavior and keep them in right track. Because of 'namosh' (feeling shame themselves), the students did not want to reveal to their family members, if they were punished by the teachers. Moreover, the parents accepted the punishment and also suggested the teachers to punish their children for getting education. In this way, the parents have positive attitude towards punishment and they think that the punishment is for the betterment of their children. The parents think that the education wouldn't come, if the children did not have fear on school in general and teacher in particular. Whenever, the children were not listening to the parents, the parents used to say that they would complaint about them to the teacher. Very often, the parents questioned their children that if they were good, why they would be punished by the teacher. The parents thought that the fault was with the students only. The parents defended teachers that they never show any discrimination on students either in educating them or in punishing them.

Mr. V. Jaganmohana Chary (70, M), says, "If we see peon, we run away from homes. If teachers are coming on the way, we try to hide ourselves in any corner. We don't want to see him face to face because of respect and fear. Our teachers are loveable. They have to guide us in a proper way. So, we have greater respect at the same time we have fear of them." 
Mrs. MunthajJaha (62, F) says "If any teacher gives punishment to us, we take it as easy and we consider it as the duty of teacher. We have not dared to complaint against teacher. If we complaint, our parents will support the teacher only. But now for the small issues also, some of the students are committing suicides. The students are very sensitive now. Hence the teacher is following bell and bill policy."

Mrs. Anjamma (67, F) says "The teacher and students have father and son/daughter relation in those days. We respect our teachers. Now there is no relation among students and teachers. Teachers are in confusion, if they punish any student, his/her parents make it as an issue and report to police as well media. If the teacher doesn't give punishment, the student will not get anything. The students are strong with their parents' support."

\section{Status of Teachers:-}

'Swadeshepoojyathe rajah - Vidvansarvathrapoojyathe' indicates that the scholar gets respect anywhere in the world but the king gets respect within his kingdom only. Teachers get good respect from the society after the priests in those days. Since the teachers get fewer salaries in those days, there is a proverb in Telugu that 'Brathakalekabadipanthulu' which means just for the sake of livelihood, they are working as teachers. During those days, the entire teaching community gives respect and fear of their superiors such as Nazirs/Inspection officers. In the same way, the students also give respect and fear of their teachers. In the past the duty of the teacher is only teaching and strict in nature. But at present, due to changes in administration and supervision of school education, teachers don't have any fear of their superior authorities and even the students don't have any fear of their teachers due to various factors. Teacher chooses friendly approach towards the students. So that the teacher is not getting enough respect. The teacher should change his nature according to the changes taken place in the society. Hence the teachers are behaving like not only as parents but also as friends. The parents' attitude towards teachers is also responsible for decreasing status of teachers. They give more lenience to their children and highlight the mistakes of teachers in front of students. Instead of explaining the students about the importance of teacher in one's life, sometimes, some of the parents are humiliating the teachers. They want to be on the side of their children. Most of the parents are not listening to the teachers ratherthey are considering the opinion of their children in several cases. Even the parents are not telling about what is right and what wrong in one's life. Increase in number of teachers when compared to the past is also another reason for decreasing status of teacher. In some of the Telugu cinemas, teachers are being shown with least priority by playing jokes on them, which is also one of the reasons for decreasing status of teacher. In this way, there are multiple factors, which are responsible for decreasing the importance/status of teacher like how thousand reasons are there for the death ofKarna in the Mahabharata.

Mr. A. Rajanna $(82, \mathrm{M})$ says, "All the schools are teacher centered like Gurukula schools in the past. After India got independence, village centered system of education introduced by establishing schools in all villages. Now the student is being given importance, where education should be imparted according to the needs, demands and interests of children."

\section{Relationship between Teacher and Student:-}

The teacher is the backbone to the education system. He/she brings the nation to the greater heights by preparing good citizens. He/she depletes the darkness of the student. In the past, teacher was an experienced sculptor who carried out a figure from dumb rock. So the future of a rock like students lies in the hands of the teacher. Previously there used to be moral teaching class once in a week during Nizam period.The teacher and student have parent and child relation. The studentsfeel fear whenever they see the teacher and give respect. Teachers can give education to the children with dedication and devotion. Even though, salaries are less, they have commitment towards the profession. Money is not important for them, because they have chosen teaching profession according to their interest. They use to do additional work for the development of school and children. They inculcate moral values among the children. So that the teacher has given lot of importance and respect not only from students but also from society. The main aim and duty of the teacher is all round development of student. Teachers try to link the subject matter with society and they illustrate with suitable examples which motivated the students to apply the knowledge for their lives. But, at present students have many sources for getting knowledge. They are checking the knowledge of the teachers. If the teacher don't prepare well for the class, the students will complaint to the Head Master and parents. Teacher should be like a student in knowing the new things, and then only he/she justifies the students. The relationship between teacher and student is decreasing day by day. The teacher and student have friendly relationship now. Emergence of Human Rights and Child Rights and also parents' support are some of the responsible factors for prohibition of any kind of punishment in present day schools. 
Mr. Agaiah (70, M) says, "Even though the teacher shows love and affection on us, we fear of him, like going near to a tiger."

Mr. Veera Swamy $(65, M)$ says “The relationship between teacher and student is like father and son. We don't roam on the roads because of teachers. If they see us anywhere they question what the work that we have there. Just only for unable to answer them for these kind of questions and fear, we never roam on the roads or streets. They use to give free tuitions at their homes. We use to invite our teachers for the marriages of our children."

Mr. K. Satyanarayana $(75, \mathrm{M})$ says, "There is no chance to turn our heads at the time of examinations. If we do that, the teacher will not allow us to write examination."

Mr. GajulaSatyanarayana (65, M) says "We fear of all teachers in general and Mathematics teacher in particular. Children started to catch mistakes of the teachers like coming late to the school and leaving the school early. Teachers don't have discipline now-a-days. They are not staying at the working place and commuting daily from the nearby towns/cities. So that most of their time is being spent in journey, which makes them to have less concentration on teaching due to physical strain. The students feel that teacher is nothing but an employee who is taking salary like other employees. Hence, they are not giving respect to the teachers, which is making the students not to fear anymore."

\section{Inculcation of 'Dignity of Labour' among Students:-}

Most of the retired teachers say that they have not hesitate to work while they are studying. They have helped their parents after the school hours. They don't feel ashamed when they are involved in their caste occupation. They have not separated the education and earning. They have learnt multiple ways to live in society on their own legs.

Mr. Rama Swamy(70, M) says, "I used to go to field along with my parents for agricultural works like cracking ground nuts, irrigation, thautam (spading) and mota (lifting water by using big bowl). My parents engage in various kinds of agricultural practices. Since the economic condition of my family is not good, I listen to my parents by engaging in whatever the work assigned by them."

Mr. Shankaraiah, $(74, \mathrm{M})$ says, "I used to sit at our sweet/mixture cart daily after my school hours to help my parents."

Mr. Hanumaiah, $(65, \mathrm{M})$ says, "I used to help my parents in the cultivation, which is also a physical exercise for me."

Mrs. MunthajJaha $(62$, F) says "I helped to my mother in the domestic work during my school days. Now the parents think that if their children engaged in any work, they will be get disturbed and get less marks. They knew that their children are living in the competitive world. Now the work and education is separated. 'Earning while learning' is not that much important now a days when compared to my school days. Most of parents are ready to spend money for their children's education due to increased awareness on education."

Mr. Rangaiah (74, M) says "For getting job only, the parents are sending their children to schools. After completing their education they live by doing job only. They won't fit for any other manual/unskilled work. Most of the parents want to see their children as doctors, and engineers etc."

\section{Conclusion:-}

The impact that education had in Andhra was lacking in Hyderabad State in general and Telangana in particular. TheNizam government discouraged the language of the majority i.e. Telugu. Urdu made as the official language which was spoken by a small sector and the majoritythat was $86 \%$ of the population spoke mainly Telugu in addition to Marathi and Kannada. The Nizam was keen on evolving an educational policy, which was directed at supersedingthe local languages by Urdu. The state-aided education was given only through Urdu or English, which confronted many of the Telugu speaking children to attend the schools during those days.

The students treat teacher as god, who is a live example for students in following moral values in the past. There was a sense of dedication among the teachers in the past. But now most of students are not identifying the teacher as a 
'man of moral values'. So that the status of teacher is diminishing gradually and slowly. Presently teacher does not earn such respect as he/she used to get more in the past. Commercialization of education is the crux of the problem so moral at schools are at bay. Inculcation of moral values depends on parents, teachers and society. When the moral values are not identified by the students around them, it is very difficult to prepare them as good citizens. The impact of teacher is more on students than the parents. Hence the teacher should practice moral values to inspire the students. A separate subject was there on moral education at school level during Nizam period. Apart from regular teaching, the teacher used to develop character and discipline among students. After Telangana merged with Indian Union, the subject was removed and moral values were incorporated into the languages. But due to Globalization and increased demand for Science education, most of the school managements, teachers and parents are neglecting school subjects such as Social Sciences and languages like Telugu and Hindi where there is a scope for inculcating moral values among students. Due to increased nuclear families, most of the students are unable to stay with their grandparents who also inculcate moral values among the children. School is being considered as an agent of scoring marks only rather than inculcation of group culture, habits, moral values and human values.

The relationship between teacher and student is like a parent and child in the past where as it is very weak at present. The student has neither respect nor devotion towards his/her teacher. Having limited off springs, increased number of teachers, impact of media on students, changing ways of teaching and democratic principles are some of the reasons for weakening the relationship between teacher and student. Most of the teachers are following 'bell and bill policy' and also they don't want to give any kind of punishment to the students. The teachers want to protect themselves from the parents, managements of schools and laws against corporal punishment. The parents are not accepting any kind of punishment to their children unlike in the past. As Durkheim said that the teacher has to change according to the changes taken place in the society from time to time. That is why the teacher has changed his way of teaching from authoritarian approach to friendly approach. In the teacher-centered teaching, teacher is allowed to give severe punishment to bring desired changes among children whereas in the student-centered teaching, the teacher should act as a facilitator for providing learning situations to the students by considering their social background and also based on principles of developmental psychology.

\section{References:-}

1. Archer, Margaret S. 1984. 'Social Origins of Educational Systems'. Sage Publications, New Delhi.

2. Blackledge, David and Barry Hunt. 1985. 'Sociological Interpretations of Education'. Croom Helm, New Hampshire.

3. Chugh, Sunitha. 2014. 'Schooling of Children Living in Slum Areas: An Analysis of Selected Households from Hyderabad and Ludhiana'. Indian Educational Review, 52 (2), pp 31-52.

4. Gore, M.S. 1982. 'Education and Modernization in India'. Rawat Publications, Jaipur.

5. Hai, Abdul. 2016. 'History of Nizams Rule and Education before Independence'. Quest Journals 4 (8):21-23.

6. Joseph, Uma T. 2006. 'Accession of Hyderabad: The Inside Story'. SundeepPrakashan, Delhi.

7. Ottaway, A.K.C. 1968. 'Durkheim on Education'. British Journal of Educational Studies 16(1):5-16

8. Raj, Sheela. 1987. 'Medievalism to Modernism: Socio-Economic and Cultural History of Hyderabad - 1869-1911', Sangam Books Limited, New Delhi.

9. Rajagopal, M.V. 1974. 'Andhra Pradesh District Gazetteers, Karimnagar'. The Government Printing Press, Kurnool.

10. Ramanaiah, Jaishetty. 2008. 'History and Culture of Karimnagar District (A.P.)'. Jaishetty Publications, Jagtial.

11. Rao, P. Raghunadha, 1994. 'History and Culture of Andhra Pradesh: From the Earliest Times to the Present Day'. Sterling Publishers Private Limited, New Delhi.

12. Rao, Y. Vittal. 1979. 'Education and Learning in Andhra under the East India Company'. VidyaranyaSwamy, Secunderabad.

13. Reid, Ivan. 1978. 'Sociological Perspectives on School and Education', Open Books, London.

14. Robins, Kevin and Webster, Frank. 1989. 'The Technical Fix: Education, Computers and Industry', St. Martin's Press, New York.

15. Snarey, John and Thomas Pavkov. 1991. 'Beyond Socialization Versus Development: Kohlberg's Approach to Moral Education'. Sociological Focus 24 (2):105-115.

16. Superintendent of Government Printing. 1909. 'Imperial Gazetteer of India'. Provincial Series Hyderabad State, Calcutta.

17. Vaikuntham, Y. 1982. 'Education and Social Change: Andhra 1880-1920'. New Era Publications, Madras.

18. Vaikuntham, Y. 2002. 'State, Economy and Social Transformation: Hyderabad State (1724-1948). Manohar Publishers and Distributors, New Delhi.

19. Vaikuntham, Y. 2004. 'Studies in Socio-Economic and Political History: Hyderabad State', Karshak Art Printers, Hyderabad.

20. Vaikuntham, Y. 2004. 'Studies in Socio-Cultural and Political History: Modern Andhra'. Karshak Art Printers, Hyderabad. 